\title{
Assessment of Quality of Life of Partners of Patients with Benign Prostate Hyperplasia: Does Benign Prostate Hyperplasia Disturb Female Partners?
}

\author{
Benign Prostat Hiperplazili Hastalarm \\ Partnerlerinin Hayat Kalitesinin \\ Değerlendirilmesi: Benign Prostat Hiperplazisi \\ Kadinları Rahatsız Ediyor mu?
}

Talha MÜEZZiNOĞLU, MD, ${ }^{\text {a }}$ Kamil ÇAM, MD, Ali KAYIKÇI, MD, Murat LEKILI, MDa

aDepartment of Urology, Celal Bayar University Faculty of Medicine, Manisa bDepartment of Urology, Düzce University Faculty of Medicine, Düzce

Geliş Tarihi/Received: 17.07.2009 Kabul Tarihi/Accepted: 21.02.2010

Yazışma Adresi/Correspondence: Kamil ÇAM, MD Düzce University Faculty of Medicine, Department of Urology, Düzce, TÜRKIYE/TURKEY kamilcam@ hotmail.com

\begin{abstract}
Objective: Benign prostate hyperplasia (BPH) is a common health problem throughout the world. The aim of the study was to evaluate the consequence of BPH on partners by using Turkish version of a specific quality of life (QoL) scale for partners of BPH patients. Material and Methods: The study group consisted of partners of $300 \mathrm{BPH}$ patients who were admitted to urology outpatient departments of two university hospitals (Düzce University and Celal Bayar University) with lower urinary tract symptoms. BPH patients were asked to fill out International Prostate Symptom Score (IPSS) form, while female partners were separately requested to complete the specific QoL questionnaire. Results: The mean age of patients with BPH was $63.8 \pm 7.2$ years and it was 56.3 \pm 6.5 years for female partners. The results of the specific questionnaire showed that QoL of partners were significantly affected. Particularly, most of the the partners had the fear of cancer development and possibility of surgery for their husbands, 77\% (231/300 partners) and 79\% (237/300 partners), respectively. At night majority of partners woke up frequently because of their husbands, however mostl of them declared no or little disturbance in terms of being tired during the day. On the other hand, it was revealed that there was a significant correlation between QoL degrees of partners and IPSS values of BPH patients ( $p<0.001$; correlation coefficient 0.664). Conclusion: BPH significantly impairs the QoL of female partners. This negative impact correlates with the IPSS values of $\mathrm{BPH}$ patients. Therefore, the physicians should also consider burden of the female partners in the management of $\mathrm{BPH}$ patients.
\end{abstract}

Key Words: Prostatic hyperplasia; prostate; quality of life

ÖZET Amaç: Benign prostat hiperplazisi (BPH), tüm dünyada yaygın bir hastalıktır. Bu çalışmada BPH'nın BPH'lı hasta partnerlerindeki etkilerinin spesifik hayat kalitesi (QoL) skalası vasıtasıyla değerlendirilmesi amaçlanmıştır. Gereç ve Yöntemler: Çalışma grubu, iki üniversite hastanesinin (Düzce Üniversitesi ve Celal Bayar Üniversitesi) üroloji polikliniklerine başvuran, alt üriner sistem şikayetine sahip 300 BPH'lı hastadan oluşmuştur. BPH hastaları Uluslararası Prostat Semptom Skoru (IPSS) ile değerlendirilirken, eșleri olan kadınlardan ayrı bir bölümde spesifik QoL anketini cevaplamaları istenmiştir. Bulgular: Yaş ortalaması BPH'lı hastalarda $63.8 \pm 7.2$ yıl, kadınlarda ise 56.3 \pm 6.5 yıl idi. Spesifik QoL anket sonuçlarına göre partnerlerin anlamlı derecede etkilendikleri tespit edilmiştir. Partnerlerin \%77'sinin (231/300) olası kanser gelişimi ve \%79'unda (237/300) operasyon ihtimali konusunda ciddi endişe taşıdığı görülmüştür. Eşlerin büyük bir kısmı kocalarından dolayı gece sık sık uyandıkları halde, gün boyu yorgunlukları hakkında hiç ya da çok az şikayetleri olduğunu belirtmişlerdir. Diğer taraftan partnerlerin QoL derecesi ile BPH'lı hastaların IPSS skoru arasında anlamlı korelasyon bulunduğu görülmüştür ( $\mathrm{p}<0.001$, korelasyon katsayısı: 0.664). Sonuç: BPH, partnerlere anlamlı şekilde rahatsızlık vermektedir. Bu rahatsızlık PBH'lı hastaların IPSS değerleri ile korelasyon göstermektedir. Bu nedenle, doktorlar BPH tedavisinde kadın partnerlerin durumunu da dikkate almalıdırlar.

Anahtar Kelimeler: Prostat hiperplazisi; prostat; yaşam kalitesi 
$\mathrm{B}$ enign prostate hyperplasia (BPH) is a common public health problem affecting millions of elderly men throughout the world. ${ }^{1}$ The treatment algorithms currently target symptoms to improve quality of life (QoL) of the individual patient. ${ }^{2,3}$ Therefore, assessment of specific QoL for the particular individual BPH patient would be mainstay step in the management rather than measuring degree of symptoms. ${ }^{4,5}$ It was shown that BPH significantly deteriorates QoL of patients. ${ }^{6,7}$ In several chronic conditions such as multiple sclerosis and prostate cancer, QoL of partners of the patients are extensively disturbed particularly in terms of having psychological stress even more than the patients. ${ }^{8,9}$ Some lower urinary tract symptoms related to $\mathrm{BPH}$, for example nocturia can obviously impair the QoL of partners. The behavior of partners towards BPH must be taken into consideration since it is one of the most common diseases effecting men. However, limited number of published data is present on this issue. ${ }^{9,10}$ Sells et al. developed and validated a specific questionnaire including nine items for partners of BPH patients in order to assess their QoL. ${ }^{11}$ They reported that presence of remarkable morbidity in the partners of patients with BPH. Moreover, they found that the degree of partner morbidity was related to the severity of the patients' symptoms. Finally they concluded that this new form was applicable to partners, filled easily and had suitable psychometric criteria. We previously validated Turkish version of this questionnaire. ${ }^{12}$

The objective of this study was to evaluate effect of $\mathrm{BPH}$ on QoL of partners by using this specific questionnaire. Meanwhile, we would compare different attitudes of partners towards BPH in different cultures.

\section{MATERIAL AND METHODS}

The study group included 300 couples whose male partners applied to urology outpatient departments of two university hospitals (Düzce University and Celal Bayar University) due to the presence of lower urinary tract symptoms related to $\mathrm{BPH}$. Initially, a short information about the study procedure and questionnaires were given to all couples and a written informed consent was obtained. Inclusion criteria included first exposure to International Prostate Symptom Score (IPSS) form. Therefore, patients who applied to a physician for the first time due to presence of symptoms associated with BPH were selected. The ones with any disability (blindness, neurological or psychiatric disorder etc.) that could impair filling the questionnaires were excluded from the study.

$\mathrm{BPH}$ patients were asked to fill out IPSS form, while female partners were requested to complete the validated Turkish version of specific QoL questionnaire. ${ }^{12}$ This specific QoL form has originally developed and validated by Sells et al. ${ }^{11}$ It composes of nine items including sleep disturbances, impairments in social and daily activities, psychological well-being, sexual performance, fear of surgery, fear of cancer, and other impact factors on QoL. When needed, further explanation was provided by a physician about a particular item. Statistical analyses were carried out using the Statistical Package for the Social Sciences-SPSS for Windows, version 6.00 software. The level of statistical significance was accepted as 0.05 . Relationship between QoL scale and IPSS was evaluated by Pearson correlation test. A normal distribution of our data was shown using the normality test.

\section{RESULTS}

Mean age of the patients with BPH was $63.8 \pm 7.2$ years, and it was $56.3 \pm 6.5$ years in the female partners. The age difference between men and women (male-female) ranged between -2 and 21 (mean 6.4 +4.7 ) years. The couples were married for $42.3+$ 9.8 years. Almost half of partners of $\mathrm{BPH}$ patients were unemployed (47\%) and majority of these women graduated from primary school (83\%).

According to results of the specific QoL of partners and questionnaire for $\mathrm{BPH}$, although the majority of partners woke up once (39\%) or twicethree times $(42 \%)$ because of their husbands, majority of them (216 partners, 72\%). interestingly declared no or little disturbance in terms of being tired during the day (question 2). 
Similarly, most of the partners apprised no or little adverse effect on their social (question 3 ) and daily (question 4 ) activities; $85 \%$ (255/300 partners) and $89 \%$ (267/300 partners), respectively.

On the other hand, almost one third of the partners (99 partners, 33\%) were worried because of urinary symptoms of their husbands (question 5). About $46 \%$ (138 partners) of the spouses declared no or little alteration in their sexual activities (question 6).

Most of the partners had the fear of development of cancer (question 7) and possibility of surgery (question 8) for their husbands; 77\% (231/300 partners) and 79\% (237/300 partners), respectively. A total of 181 patients (60\%) declared dissatisfaction (question 9) regarding the possibility of no subsequent improvement in the degree of urinary symptoms of their husbands. The distribution of partners regarding the items of QoL scale is shown in Figure 1.

The assessment of partner QoL scale revealed a significant correlation with IPSS scores of BPH patients. The correlation relationships of partner QoL questionnaires were $\mathrm{r}=0.664(\mathrm{p}<0.001)$ with the total IPSS score, $r=0.647(p<0.001)$ with the irritative symptoms score of IPSS, $\mathrm{r}=0.578(\mathrm{p}<$ 0.001 ) with obstructive symptoms score of IPSS, and $r=0.668(p<0.001)$ with QoL score of IPSS.

\section{DISCUSSION}

Assessment of QoL is a rather new issue with a considerably increasing interest in almost every field of medicine. Particularly, QoL studies gain

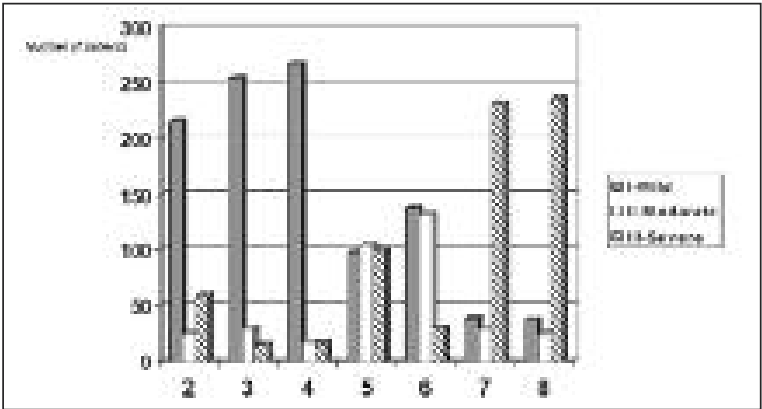

FIGURE 1: The distribution of partners of BPH patients according to the each particular item of QoL scale. tremendous emphasis regarding the chronic conditions, especially cancer cases. The concept of QoL is included in the recent treatment algorithms of various disorders. In fact, a newly proposed treatment option should also target the improvement of QoL as it aims patients' satisfaction and happiness. Similarly, contemporary approach in the management of BPH suggests relief of symptoms in order to improve QoL of each particular patient. ${ }^{2,3} \mathrm{BPH}$ with an increasing incidence represents a major health problem for elderly men. It has been clearly shown that BPH deteriorates QoL of patients. ${ }^{6,7}$ In an interesting trial performed on $189 \mathrm{BPH}$ patients who were on the waiting list for surgery, the QoL of BPH patients was found to be poorer than that of the general population of the same age by short-formula 36 (SF-36). ${ }^{13}$ The deterioration in QoL was in parallel with the degree of symptoms. Since it is a common chronic condition, the attitude of female partners towards BPH maybe have some detrimental effects on their QoL. The QoL of spouses has been focused in several chronic conditions, particularly in cancer. In a recent observation it was concluded that partners do not solely provide support, but need support themselves many years after a cancer diagnosis. ${ }^{14}$ It was observed that even psoriasis could cause a significant burden in QoL of the partners of the patients. ${ }^{15}$ The authors concluded that realizing QoL issues allows clinicians to introduce appropriate care strategies not only for patients with psoriasis, but also for their partners and even family. Therefore, assessment of QoL in partners of BPH may provide significant information with possible clinical consequences. However, in literature a limited number of studies have handled this issue although BPH is a chronic disease with a significantly high prevalence. Sells et al. first time developed and validated a specific QoL questionnaire for partners of patients with $\mathrm{BPH} .{ }^{11}$ We then provided the reliability and validation analysis of Turkish version of this questionnaire. ${ }^{12}$ It would be a valuable tool to analyze the situation of partners of patients in terms of cultural differences regarding the perception of BPH symptoms. Results of these studies may guide the physician and lead to 
inform the couple together about the status of $\mathrm{BPH}$ disease including mutual discussion on treatment alternatives.

Current study revealed that QoL of partners severely affected due to the presence of $\mathrm{BPH}$ in their partners. Approximately one third of partners (33\%) were worried because of lower urinary symptoms of their husbands. Interestingly, more than half of the female partners reported that they would be disappointed if no subsequent improvement would be achieved in the degree of urinary symptoms of their husbands.

Regarding the specific issues of this particular QoL questionnaire, some cultural differences can be observed in the perception of BPH-related symptoms by the female partners. Sells et al. reported that nearly half of the partners felt tired the next day because of waking up more than once at the night. ${ }^{11}$ In the Greek study, majority of partners did not report sleep disturbances, similar to our population. ${ }^{10}$ The degree of alteration in the sexual performance also varied greatly in these three studies. Sells et al. reported that two-thirds of partners had noticed worsening in their sex life. ${ }^{11}$ Sex life was moderately or severely altered in $26 \%$ and $22 \%$ of Greek partners. ${ }^{10}$ We observed no or limited change in sexual performance in half of the cases. On the other hand, majority of partners worried for the presence of prostate cancer in their husbands, and most partners were worried about the possibility of an operation in the English study. ${ }^{11}$ A similar perception regarding the fear of cancer and surgery has been obtained both in Greek study and in our study. Therefore, it can be concluded that the physician should inform the spouses of BPH patients about the risk of prostate cancer and indications for BPH surgery since these issues caused anxiety in these three different cultures. The study group of our research were composed of a relatively sufficient number of couples, however previous similar observations were based on 90 and 50 couples, respectively. Subsequent trials are required to explore cultural variations in the perception of lower urinary tract symptoms for female partners Nevertheless physicians should not ignore the female partners and should at least provide the basic information about properties of the $\mathrm{BPH}$ disease.

In conclusion, it was shown that BPH significantly impaired QoL of BPH patients. Since BPH represents a common chronic condition, assessment of QoL of partners of patients with $\mathrm{BPH}$ should not be ignored. This study revealed that $\mathrm{BPH}$ remarkably deteriorated the QoL of partners of BPH patients. Therefore, the spouse should be informed about the BPH disease. She may take part at least in the decision making process, and thenegative feelings originating from misinterpretation of urinary symptoms of in their partners may be avoided.

\section{REFERENCES}

1. Lekili M, Muezzinoglu T. [Benign prostate hyperplasia: epidemiology and natural history]. Turkiye Klinikleri J Surg Med Sci 2005;1(1):1523.

2. Garraway WM, Collins GN, Lee RJ. High prevalence of benign prostatic hypertrophy in the community. Lancet 1991;338(8765):46971.

3. Madersbacher S, Alivizatos G, Nordling J, Sanz CR, Emberton M, de la Rosette JJ. EAU 2004 guidelines on assessment, therapy and follow-up of men with lower urinary tract symptoms suggestive of benign prostatic obstruction (BPH guidelines). Eur Urol 2004:46(5):547-54.

4. Chapple CR. The total approach in lower uri- nary tract symptoms/benign prostatic hyperplasia (LUTS/BPH) management: introduction and conclusions. Eur Urol 2003;62 (3 Suppl 1):1-5.

5. Zorlu F, Muezzinoglu T. [Quality of life in urological oncology]. Turkiye Klinikleri J Surg Med Sci 2005;1(9):105-12.

6. Ushijima S, Ukimura O, Okihara K, Mizutani Y, Kawauchi A, Miki T. Visual analog scale questionnaire to assess quality of life specific to each symptom of the International Prostate Symptom Score. J Urol 2006;176(2):665-71.

7. Trueman P, Hood SC, Nayak US, Mrazek MF. Prevalence of lower urinary tract symptoms and self-reported diagnosed 'benign prostatic hyperplasia', and their effect on quality of life in a community-based survey of men in the UK. BJU Int 1999;83(4):410-5.

8. Knight RG, Devereux RC, Godfrey HP. Psychosocial consequences of caring for a spouse with multiple sclerosis. J Clin Exp Neuropsychol 1997;19(1):7-19.

9. Kornblith AB, Herr HW, Ofman US, Scher HI, Holland JC. Quality of life of patients with prostate cancer and their spouses. The value of a data base in clinical care. Cancer 1994;73(11):2791-802

10. Mitropoulos D, Anastasiou I, Giannopoulou C, Nikolopoulos P, Alamanis C, Zervas A, et al. Symptomatic benign prostate hyperplasia: impact on partners' quality of life. Eur Urol 2002;41(3):240-4. 
11. Sells $H$, Donovan J, Ewings $P$, MacDonagh RP. The development and validation of a quality-of-life measure to assess partner morbidity in benign prostatic enlargement. BJU Int 2000;85(4):440-5.

12. Çam K, Muezzinoğlu T, Kayıkçı A, Aydemir Ö. [Validity and reliability of Turkish version of quality of life scale specific for partners of pa- tients with benign prostatic hyperplasia]. Turkiye Klinikleri J Nephrol 2010;5(1):1-5.

13. Salinas-Sánchez AS, Hernández-Millán I, Lorenzo-Romero JG, Segura-Martin M, Fernández-Olano C, Virseda-Rodriguez JA. Quality of life of patients on the waiting list for benign prostatic hyperplasia surgery. Qual Life Res 2001;10(6):543-53.
14. Hodgkinson K, Butow P, Hunt GE, Wyse R, Hobbs KM, Wain G. Life after cancer: couples' and partners' psychological adjustment and supportive care needs. Support Care Cancer 2007;15(4):405-15.

15. Eghlileb AM, Davies EE, Finlay AY. Psoriasis has a major secondary impact on the lives of family members and partners. $\mathrm{Br} \mathrm{J}$ Dermatol 2007;156(6):1245-50. 
Copyright of Turkiye Klinikleri Journal of Medical Sciences is the property of Ortadogh Reklam Tanitim ve Yayincilik Turizm Egitim Insaat Sanayi ve Ticaret A.S. and its content may not be copied or emailed to multiple sites or posted to a listserv without the copyright holder's express written permission. However, users may print, download, or email articles for individual use. 